Science, Philosophy and Religion

The Eddington Memorial Lectures have come to occupy a special place in the scheme of things, because they enable men of distinction to illuminate some particular facet of the working of that great mind. In his recent lecture entitled "Science, Philosophy and Religion" (pp. iv +31 . Cambridge : University Press, 1959. 4s. 6d. net), Sir Russell Brain shows how the analysis of man, science and revelation, man and mechanization, perception and knowledge fit into the main stream of Eddington's thought; and this because the author is dealing with someone who was all at once Quaker, mystic, mathematician, astronomer and metaphysician. If one lesson emerges clearly from pondering upon Eddington's philosophy, it is that a new concept will be needed to enable us to explain total behaviour in a way which transcends individual components. This is well said for biological systems, but it (or something very like it) is becoming essential for inanimate phases, too, as witness the present discontents with 'classical' quantum theory. Ratiocination will try its hardest, though maybe these regions form part of the unseen world to which, as Eddington says, the human spirit must turn.

\section{Design for Tropical Living}

Growing interest in the effects of environmental factors on life in tropical regions is to be found in the number of conferences and specialist meetings which have been held during the present decade. In 1951 an informal meeting was held in London to discuss co-operative research on building problems arising in hot climates. Unesco has organized two symposia, one held in New Delhi in 1952 to study the application of scientific principles, and one in Uganda in 1955 dealing with geographical factors in relation to the design of tropical buildings in the development of tropical Africa. The United States Building Research Advisory Board arranged a conference in Washington in 1953 on building in hot-humid and hot-dry climates, while in the same year, ecological problems arising from technical developments in tropical and sub-tropical countries were considered at an informal seminar held at Cambridge.

In 1955 medical and other aspects of African housing were considered at a conference under the ægis of the East African Advisory Committee for Medical Research in Nairobi. The Australian Academy of Science held a symposium in Brisbane in 1956 on man and his animals in the tropics, while in September 1958 the Scientific Council for Africa South of the Sahara arranged a specialists' meeting at Lagos on environmental factors affecting the physiology of man. The findings of these and other investigations were brought together during an admirable symposium arranged by the Natal Regional Research Committee of the South African Council for Scientific and Industrial Research and the University of Natal at Durban on October 18, 1957. The papers dealt with the climatic environment, deterioration of materials, physiological aspects of design for tropical living, psychological aspects of life in a warm climate, town and regional planning, climatic control by building, design, air conditioning in the tropics, and architecture in the tropics. These, and the ensuing discussion, have been published in a report (Symposium on Design for Tropical Living. Pp. vii+222. Pretoria, 1958) prepared by the National Building Research Institute of the South African Council for Scientific and Industrial Research.

\section{Report of the Smithsonian Institution}

THE annual report of the Board of Regents of the Smithsonian Institution for the year ended June 30 , 1957 (cf. Nature, 181, 1709 ; 1958), has now been published as a bound volume (pp. $x+499+74$ plates. Washington, D.C. : Government Printing Office, 1958. 4.50 dollars) with a general appendix, including memoirs and reports of investigations made by members of the staff of the Institution or collaborators. Among those not previously published or not easily available may be mentioned E. B. Roberts's review of the United States Coast and Geodetic Survey, 1807-1957; Prof. T. Gold's James Arthur lecture, "Cosmic Rays from the Sun"; F. L. Whipple's "Meteors"; J. M. Chamberlain's "The Development of the Planetarium in the United States"; R. Lee's "Jet Streams"; E. B. Leopold and R. A. Scott's "Pollen and Spores and their Use in Geology"; Prof. R. E. Crist's "The Land and Pcople of the Guajira Peninsula"; M. C. Leikind's "Aniline Dyes-Their Impact on Biology and Medicine"; and T. D. Stewart's "Stone Age Skull Surgery". A limited number of reprints of the papers are available on application to the Editorial and Publications Division, Smithsonian Institution.

\section{Rand Corporation Publications}

THE Rand Corporation has presented to the Science Museum Library, as a national deposit collection for Great Britain, a set of nearly 1,000 of its research publications. These range through mathematics, physics, electronics, aeronautics, economics, and the social and political sciences. They are now available for loan to all registered borrowers from the Science Museum Library, and to anyone as photocopies through the Science Museum Library Photocopy Service. The Index to the Rand Corporation Publications is held at the Science Museum Library, but is not for loan. Copies of the Index have also been deposited in the larger university libraries of Great Britain.

\section{Design of Office Chairs and Tables}

General principles which may be applied to the design of chairs and tables can be discerned in the results of a number of researches undertaken during the past few decades in several related biological fields. Studies of anatomical structure and function have given information as to where support for the body should or should not be provided. Clinical evidence demonstrates the results of insufficient attention to body mechanics. Studies of the times at which different muscle groups come into play and become fatigued in various activities, and the extent of their action in different positions, indicate the relative physiological efficiency of different working postures. Many anthropometric surveys have now been made with application to a wide variety of practical, industrial and military problems.

From these studies Dr. W. F. Floyd and Dr. D. F. Roberts have selected the findings relevant to the dimensions and design of office chairs and tables and summarized them in a report published by the British Standards Institution (Anatomical, Physiological and Anthropometric Principles in the Design of Office Chairs and Tables. B.S.3044, 1958. 5s. net). Among the factors considered are: posture, supporting the trunk weight, seat height, seat depth, seat width, tie rails, trunls stabilization, the backrest and table height. The report contains a biblio- 